\title{
Effect of Selected Occupational Health and Safety Management Practices on Job Satisfaction of Employees in University Campuses in Nakuru Town, Kenya
}

\author{
Florence Sembe*, Amos Ayuo \\ Department of Business Administration, Egerton University, Nakuru, Kenya \\ Email address: \\ sembeakinyi@yahoo.com (F. Sembe),ayuoamos@gmail.com (A. Ayuo) \\ ${ }^{*}$ Corresponding author
}

\section{To cite this article:}

Florence Sembe, Amos Ayuo. Effect of Selected Occupational Health and Safety Management Practices on Job Satisfaction of Employees in University Campuses in Nakuru Town, Kenya. Journal of Human Resource Management. Vol. 5, No. 5, 2017, pp. 70-77. doi: $10.11648 /$ j.jhrm.20170505.11

Received: May 28, 2017; Accepted: June 12, 2017; Published: October 16, 2017

\begin{abstract}
Occupational Health and Safety (OSH) is defined as the science of anticipation, recognition, evaluation and control of hazards arising from the workplace that could impair the wellbeing of workers. It is a cross-disciplinary area that is concerned with protecting the safety, health and welfare of people engaged in employment or work. It is against this background that the research project was carried out to find the effect of selected Occupational health and Safety management practices on job satisfaction of employees in University Campuses in Nakuru Town, Kenya. The study was guided by the following objectives: to determine the effect of selected welfare management practices on job satisfaction, to determine the effect of emergency management practices on job satisfaction, to determine the effect of workplace environment practices on employee job satisfaction and to determine the combined effect of welfare management practices, emergency management practices and workplace management practices on employee job satisfaction. The target population comprised of 258 samples of non-teaching staff, in all the University Campuses situated in Nakuru. Census was conducted to select data. Data was collected using questionnaires; Data analysis for all the objectives was done using multiple regression analysis, and descriptive statistics such as frequencies, tables, charts, and graphs. Hypothesis testing in all the objectives was done using Pearson's correlation and regression analysis. The study is of importance to the management of university campuses in establishing the effect of selected occupational health and safety management practices on job satisfaction of employees in University campuses in Nakuru Town, Kenya. The findings revealed that the practice of occupational health and safety management practices leads to improved job satisfaction among employees. The study recommends that Universities should invest in occupational health and safety issues that concern employees. Areas for further study identified include challenges in the implementation of occupational health and safety management practices on organizational work environment.
\end{abstract}

Keywords: Occupational Health and Safety, Job Satisfaction, University Campuses

\section{Introduction}

\subsection{Background of the Study}

Occupational safety and health (OSH) is generally defined as the science of the anticipation, recognition, evaluation and control of hazards arising from the workplace that could impair the health and well-being of workers, taking into account the possible impact on the surrounding communities and the general environment [12]. It is a cross-disciplinary area concerned with protecting the safety, health and welfare of people engaged in employment or work.

According to the International Labor Organization [14] and the World Health Organization [4] global strategy on occupational health for all, occupational safety and health is aimed at the promotion and maintenance of the highest degree of physical, mental and social well-being of workers in all occupations; prevention among workers from leaving work 
due to health problems caused by their working conditions; protection of workers in their employment from risks resulting from factors adverse to their health; placing and maintenance of the worker in an occupational environment adapted to his or her physiological and psychological capabilities and adaption of work to the person and of each person to their job [1].

The literature on workplace safety and health administration reveals that much of the subject has been covered in different parts of the world. The areas covered tends to focus predominantly on disease prevention, psychosocial factors at the workplace, safety concerns at the workplace, workplace politics, workplace spirituality, epileptic medication at the workplaces, safety climate at the workplace, safe management, exposures to chemicals and perceptions of risks [11].

In Africa, studies on human perception and experience of environmental safety management are scarce. These studies tend to focus on behavioral qualities of the workers at the workplaces [3] and on issues such as occupational hygiene, global equity challenges, policies, problem solving, welding health hazards, health education, asbestos problems, responsibility assignment, health and safety and equity in the workplace [4].

According to [5], the status of Occupational health and safety conditions in Kenya is an issue of growing importance to the industrialists, practitioners, the Government and consumers. Occupational health and safety issues are anchored in the ministry of labor. The health, safety and Welfare of persons employed in factories and other places of work is provided in the Factories Act cap 514, (2007). The Act is predominantly socioeconomic in nature and focuses on the shop floor conditions of factories, safety devices, machine maintenance, safety precautions in case of fire, gas explosions, electrical faults, provision of protective equipment among others [16].

Occupational health and safety effects are important for organizations. Working in a safe environment leads to job satisfaction of employees. Leading to Job value, contentment, excitement, attachment to their job, reduced absenteeism, punctuality and low turnover rates.

\subsection{Statement of the Problem}

Occupational Safety and Health practices play a significant role in any work environment. Effective implementation OHS management practices such as emergency, welfare and workplace environment may lead to employee job satisfaction. This is because the practices foster a sense of security, comfort and belongingness in the minds of employees. This eventually translates into job satisfaction [14]. Hence many organizations attach a lot of importance to OHS management practices. A lot of organizational investment in terms of finance, training, time and physical resources are usually directed towards ensuring effective implementation of OHS management practices [2]. In Kenya, there has been a rapid expansion of Universities necessitating the need to establish campuses to accommodate the students. This has resulted into university campuses being established in all major towns of Kenya. Some of these campuses are, however, located along highways, roads streets, near shops, factories and near risky environment. This scenario exposes the employees to risks such as: terrorism, fire disasters, armed robberies and pollution among others [5] In cognizance of the role played by effective OHS management in relation to job satisfaction of employees who work in organizations prone to risks such as afore mentioned, many scholars and policy makers have turned their attention to OHS management practices as a field of study. A study conducted by [12] on the relationship between OHS practices and Job satisfaction of employees in hospitals India. The findings indicate a significant positive relationship between OHS practices and job satisfaction. Other scholars [4]. Study by [6] also studied the relationship between OHS management practices and job performance of employees in hospitals in Ghana. The findings suggest that OHS practices lead to job satisfaction. Most of such studies were done in developed countries and profit making organizations. In Kenya similar studies have been conducted in manufacturing firms targeting employees working in industries and workshops. There is need to confirm whether similar outcomes would be replicated in non-manufacturing firms, especially in academic institutions. This study therefore answers the question: What is the effect of selected Occupational, Health and Safety management on job satisfaction of employees in University Campuses in Nakuru Town, Kenya.

\subsection{Research Objectives}

i. To determine the effect of welfare management practices on job satisfaction.

ii. To determine the effect of emergency management practices on job satisfaction.

iii. To determine the effect of workplace environment management practices on employee job satisfaction.

iv. To determine Occupational safety health and management practices, on employee job satisfaction

\subsection{Research Questions}

Ho1: There is no significant effect of welfare management practices on employees' job satisfaction.

Ho2: There is no significant effect of emergency management practices nonemployees' job satisfaction.

Ho3: There is no significant effect of workplace environment on employees' job satisfaction.

Ho4: There is no combined effect of Occupational safety and health management practices on employees' job satisfaction. 


\subsection{Conceptual Framework}

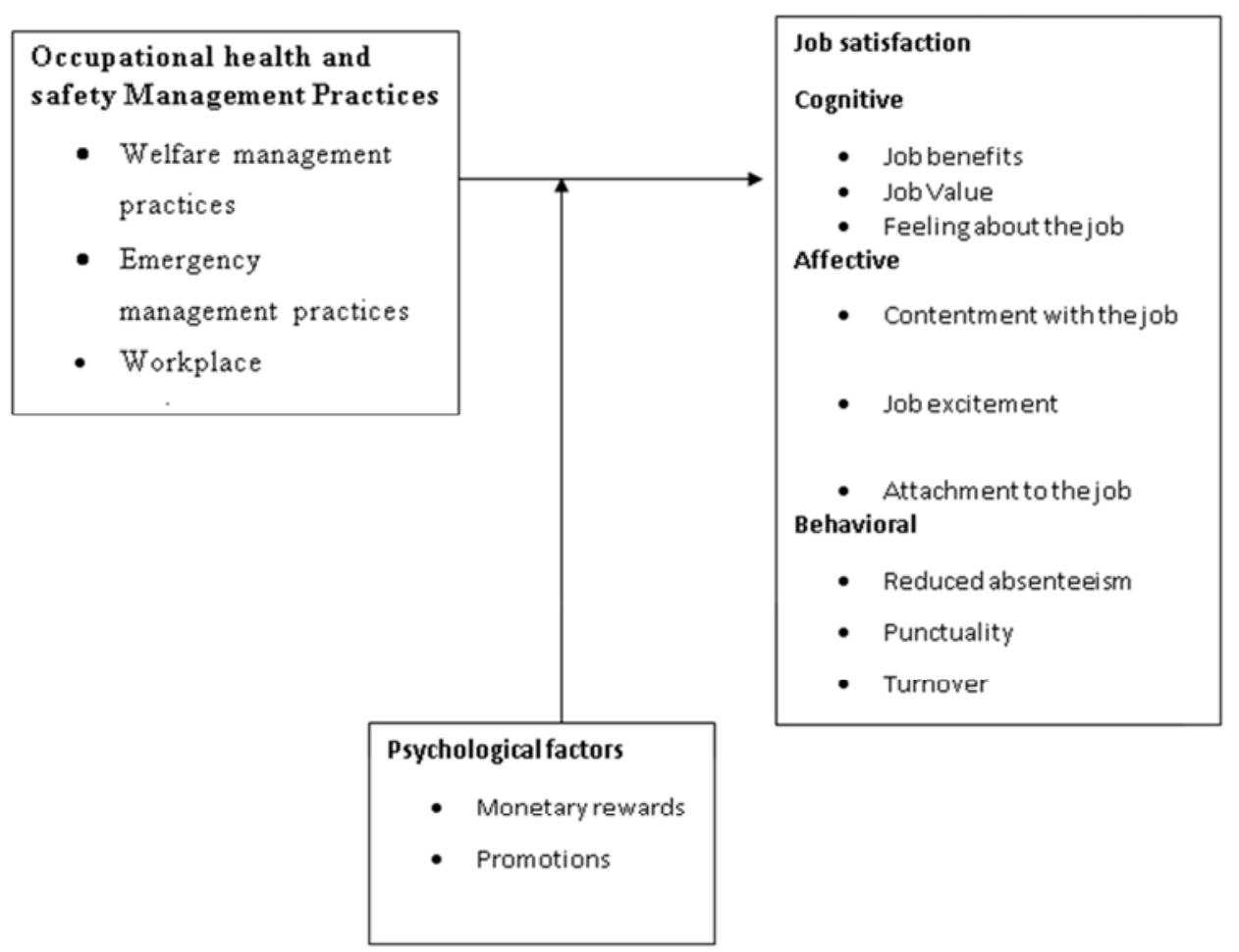

Figure 1. Conceptual Framework.

\section{Literature Review}

\subsection{Occupational Health and Safety at Workplace}

WHO and ILO define occupational health and safety as the prompt and maintenance of the highest degree of physical mental and social wellbeing of workers in all occupations [22] physical, mental and social well-being can be improved by implementing human resource management (HRM) strategies that focus on occupational health and safety in the work place (also known as Occupational health and Safety management). Report by [8] explain how occupational health and safety management is related to all actions surrounding improvement and maintenance of health and safety, the prevention and reduction of potential health and safety hazards and risks in the workplace. Study by [4] define safety hazards or those aspects of the work environment that can harm an employee. For example, physical factors like noise, vibration and heat, chemical factors poison and toxics, hazardous substances like dusts, oil, and coal, workplace organizations like repetition of work, supervision, trainings, stress and violence [15]. Occupational, health and safety practices are diverse, stress management rehabilitation programs, noise control, hazardous or dangerous substances and general health promotion [18]

\subsection{Job Satisfaction}

Job satisfaction is a combination of cognitive, affective and behavioral circumstances that cause a person to be satisfied with his or her job. It can be under influence of many external factors, but it remains something internal that has to do with how an employee feels. It presents a set of factors that cause a feeling of satisfaction [14].

Job satisfaction can be influenced by cognitive factors which include job benefits, Job value, and feelings about the job. Affective factors include contentment with the job excitement and attachment with the job. Behavioral includes reduced Absenteeism, punctuality at work and low turnover rates. When employees are rewarded they feel equal and satisfied resulting into great performance. Satisfaction may not only lead to individual performance but institutional improvement. The higher the level of job satisfaction, the lower the absenteeism rate and higher employee loyalty. The best way to reduce employee dissatisfaction would be through an increase in the level of job satisfaction. The indicators of job satisfaction include low turnover rates, high performance, and reduced absenteeism and decreased accidents rates. Psychological factors like monetary rewards and promotions are also indicators of job satisfaction [14]

\subsection{Welfare Management Practices and Job Satisfaction}

Welfare practices in organizations refer to various services offered to employees by the employer. It includes services like benefits and facilities offered to employees, not necessarily monetary but in any kind. This includes drinking water outlets, adequate toilet facilities, and adequate parking space and canteen services [4]. This fringe benefit by the employer makes life better for the employees and motivates them for better performance.

Welfare activities are categorized into two, Intramural and Extramural. Intramural activities are facilities provided by the 
organization such as medical benefits, clean water, clean toilet facilities, adequate parking space, canteens and compensation for accidents. Extramural activities include housing, sports and Educational facilities, for both parents and children [2].

Studies done on impact of employee welfare facilities and job satisfaction in South Central Railway, India have shown that proper welfare management of employees leads to job satisfaction [17].

\subsection{Emergency Management Practices and Job Satisfaction}

Emergency management is the managerial function charged with creating the framework within which communities reduce vulnerability to hazards and cope with disasters. Emergency promotion programmes and practices are important in the promotion of safety in both private and public universities. It has led to the concept of motivation; individual monetary incentives example, cash awards, promotions recognitions and recommendation letters as well as praises and feedbacks like congratulatory notes [20]. Public Universities use safety campaigns that focus on employee attention on specific accidents that are frequent in the organizations. Safety training, seminars and workshops whose main focus is on safety issues, posters and drawings, written emergency plan that covers emergency situations, first aid equipments, mechanism for alerting staff in case of an emergency, evacuations procedures, possible threats at workplace and a trained officer on disaster management. This is intended to raise safety awareness amongst employees, and senior management to make safety an integral feature in job performance, hence less accidents and therefore increase in productivity.

Communication on emergency procedures is key in promotion of safety in the universities workplace examples include sensitization on how to use personal protective equipments anti-smoking campaigns, pictures and drawings on safety issues. Safety messages are used to evoke a high level of concern amongst employees and stress positive benefits of safety prevention activities, guidelines for risk deduction and response, use of statistics or risk data should be specific to the workplace [2].

A study conducted in the aftermath of a natural disaster, discovered that "tangible support," aimed at primary post-disaster needs are food, transportation, and housing this may help reduce employees' health-related strains. In this way, relief efforts may serve to control absenteeism and workers' compensation costs, which will likely increase when a disaster has affected most of the workforce [21]

\subsection{Workplace Environment and Job Satisfaction}

Work environment is the location where a task is performed. It involves the physical location as well as the immediate surroundings of a place such as a construction site or office building. It involves factors relating to the place of employment such as noise level, quality of air and adequate parking space.

There is a link between employee health, lost work time and productivity. Universities are now making their workplace environment more conducive to its employees. Organizations with most effective work environment have shown profitable returns, higher market premiums and report more profits per employee [21] Employees with more conducive and safe workplace environment have low turnover rates as compared to companies or institutions with risky and unsafe workplace environment. Safe workplace environment leads to positive behavior amongst employees and better performance. Employees working in dangerous environment [13] perform poorly in their jobs and have low intentions to stay with the same employer. Healthy workplace leads to a healthy business matrix.

The concept of work environment includes the physical, psychological and social aspects that make up the working condition. It has both negative and positive effects on the welfare of employees. Physical condition of work can affect the health of employees' examples noise, work equipment, heat, workload task and complexity of the work, clean and well ventilated office, enough lighting, measures of controlling risks, suitable chairs for use in the offices, maintenance of furnitures, adequate lighting in offices and enough space for performing tasks. Unfriendly mental environmental condition leads to fatigue and boredom attitude, social environment affects confidence level of employees [9]. A job that is interesting and permits one to contribute one's skills and ideas is very important. Improving working conditions and providing adequate resources enhances job satisfaction.

\subsection{Welfare, Emergency, Work Environment and Job Satisfaction}

The effectiveness of welfare programmes shows that the use of incentives for welfare participation programmes can significantly reduce turnover rates and increase a sense of belonging. Successful welfare programmes can be identified by universities having effective communication strategies to communicate welfare programmes, information to employees raging from face to face interaction to mass dissemination. Opportunity for employees to engage in activities that is convenient and easily accessible for all employees and strategies that raise employee engagement like rigid work schedules. Leadership engagement at all levels in universities, continuous improvement and evaluations are used to improve welfare programmes in organizations [2].

The aim of emergency management programmes in both public and private universities is to help employees improve their own protective behavior and that of fellow workers. Emergency promotion entail safety awareness at all levels in Universities safety goals. The emergency promotions play an important role by improving workplace safety, facility planning, employee training and supervision, personal protective equipments, environmental maintenance, emergency responses and rehabilitation [26].

The productivity of employees is determined by the work environment. This involves several aspects which react or act on the body and mind of the employee. Effective work 
environment encourage employees to be satisfied with their work. Working in unfriendly environment causes fatigue and monotony thereby minimizing work performance.

Job satisfaction can be measured by human resource (HR) related evaluations, since the human resources are the most essential assets of an organization [15]. HR related measurements mostly evaluate the productivity losses and gains regarding the health and safety for example absenteeism, accidents of the employees which can be translated into costs for the Public Universities. Employee job satisfaction can be assessed by the statistics of accidents, illnesses and injury rates by eliminating accidents employee job satisfaction gains [13]. A second method is to measure universities employee job satisfaction by rate of absenteeism [7] and turnover rates [4]. These are seen as a cost that must be reduced to improve university employee's job satisfaction [13]. In addition, because workers compensation claims are related to the economic appraisal of organizational performance it is also an important measurement. Although it is found that accidents, illnesses, injuries, absenteeism turnover productivity losses (lost time) can also affect corporate image. It is argued that employee job satisfaction should be measured, by both tangible and intangible measurements. Accordingly, employee performance, motivation, well-being and job satisfaction [9] are intangible (HR related) indicators of job satisfaction; they relate and gauge one of the essential organizational performance measurements productivity (and thus money) [5]. Besides, these measurements can also affect other indicators which are more directly related to the vital measurements of job satisfaction (cost and productivity). For example, wellbeing correlates with absenteeism and productivity [21] job satisfaction affects absenteeism and turnover [10] and turnover can be negatively associated with (firm) productivity [22] Performance, motivation, wellbeing and job satisfaction assessments mostly rely upon employees.

\section{Methodology}

The study adopted a census survey design, so as to obtain opinions on selected occupational health and safety management practice on job performance. The study was conducted in Nakuru, a Town in the Rift Valley region of
Kenya. The target population of the study was non-teaching staff in university campuses in Nakuru Town. The categories interviewed included the support staff, Administrative staff and Safety and health officers in the universities. They were estimated to be 258 in number.

The researcher requested for prior permission through a request letter to the identified campuses for the data collection exercise. Structured and unstructured questionnaires were used for primary data collection. Questionnaires were used because of the simplicity in their administration, scoring of items and analysis [21] the researcher used a drop and pick method whereby, the questionnaires were distributed to the individuals and then collected the following day.

The study adopted descriptive statistics which included; summary tables mean, standard deviation, frequencies in the analysis of data collected. Inferential statistics was also used for data analysis. The study specifically employed the relevant measures of association namely; Pearson moment correlation and simple linear regression analysis. The choice of these inferential statistics allowed the researcher to infer the findings of the study to other such similar situations covered by the study. Hypotheses' testing was done using Pearson's correlation and regression analysis. The correlation between the first objectives stating that there is no significant effect of welfare management and job satisfaction, was done using linear regression analysis. The second objective that states no significant effect of emergency management practice on job satisfaction and the third objective which stated that there is no significant effect of workplace environment and job satisfaction was also done using linear regression analysis. The combined effect of occupational health and safety management practices on job satisfaction was analyzed by use of multiple regression analysis.

\section{Results and Discussion}

\subsection{Correlation Analysis}

Pearson correlation was used to establish the relationship between occupational health and safety practices and job satisfaction. The correlation analysis matrix table 1 gives the summary of the results obtained.

Table 1. Correlation matrix of occupational health and safety management practices on job satisfaction of the employees.

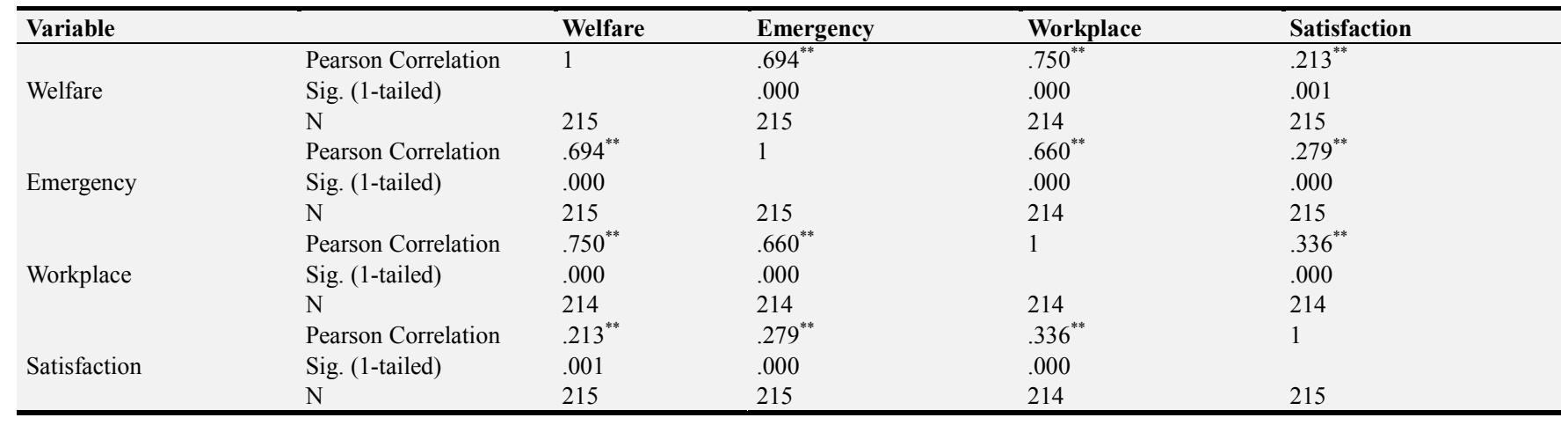

**. Correlation is significant at the 0.01 level (1-tailed). 
A correlation analysis with single tailed Pearson's test was conducted to establish the relationship between welfare management practices and job satisfaction of employees. The results were as shown in table 4, Pearson's correlation (r) indicates the correlation between welfare management practices and dependent variable, job satisfaction. The $r$ value of 0.213 indicates a positive correlation between welfare management practices and job satisfaction. The significance value of 0.001 which is less than 0.01 indicates that the relationship is statistically significant. Therefore, it was concluded that welfare practices have statistically significant positive relationship with job satisfaction. This relationship agreed with the findings of [24] where the study indicated that fringe benefits by the employer makes life better for the employees and motivates them for better performance. Similar studies by [23], showed that that proper welfare management of employees leads to job satisfaction.

The results shown in table 1, Pearson's correlation (r) indicates the correlation between emergency management practices and job satisfaction. The $r$ value of 0.279 indicates a positive correlation between welfare management practices and job satisfaction. The significance value of 0.000 which is less than 0.01 indicates that the relationship is statistically significant. Therefore, it was concluded that emergency management practices have statistically significant positive relationship with job satisfaction. According to [23], safety training, seminars and workshops whose main focus is on safety issues, posters and drawings, written emergency plan that covers emergency situations, first aid equipments, mechanism for alerting staff in case of an emergency, evacuations procedures, possible threats at workplace and a trained officer on disaster management. This is intended to raise safety awareness amongst employees, and senior management to make safety an integral feature in job performance, hence less accidents and therefore increase in productivity.

The results shown in table 1, Pearson's correlation (r) indicates the correlation between work place environment and job satisfaction. The $r$ value of 0.336 indicates a positive correlation between work place environment and job satisfaction. The significance value of 0.000 which is less than 0.01 indicates that the relationship is statistically significant. Therefore, it was concluded that work place environment have statistically significant positive relationship with job satisfaction. There is a link between employee health, lost work time and productivity. Universities are now making their workplace environment more conducive to its employees. Past studies have indicated that organizations with most effective work environment have shown profitable returns, higher market premiums and report more profits per employee [24] and that employees with more conducive and safe workplace environment have low turnover rates as compared to companies or institutions with risky and unsafe workplace environment [25]. Also, unfriendly mental environmental condition leads to fatigue and boredom attitude, social environment affects confidence level of employees [9].

\subsection{Regression Analysis}

Multiple regression analysis was conducted to establish the effect occupational health and safety. The results were as shown in table 2-3.

Table 2. Model Summary.

\begin{tabular}{lllll}
\hline Model & R & R Square & Adjusted R Square & Std. Error of the Estimate \\
\hline 1 & $.356^{\mathrm{a}}$ & .126 & .114 & .64333 \\
\hline
\end{tabular}

Predctors: (Constant), Workplace, Emergency, Welfare

Table 3. ANOVA Table.

\begin{tabular}{llllll}
\hline Model & & Sum of Squares & Df & Mean Square & F \\
\hline \multirow{3}{*}{1} & Regression & 12.575 & 3 & 4.192 & $.000^{\mathrm{a}}$ \\
& Residual & 86.914 & 210 & .414 \\
& Total & 99.490 & 213 & & \\
\hline
\end{tabular}

a. Predictors: (Constant), Workplace, Emergency, Welfare

b. Dependent Variable: Satisfaction

Table 4. Table of Coefficients.

\begin{tabular}{|c|c|c|c|c|c|c|}
\hline \multirow{2}{*}{\multicolumn{2}{|c|}{ Model }} & \multicolumn{2}{|c|}{ Unstandardized Coefficients } & \multirow{2}{*}{$\begin{array}{l}\text { Standardized Coefficients } \\
\text { Beta }\end{array}$} & \multirow{2}{*}{$\mathbf{T}$} & \multirow{2}{*}{ Sig. } \\
\hline & & B & Std. Error & & & \\
\hline \multirow{4}{*}{1} & (Constant) & 3.193 & .211 & & 15.164 & .000 \\
\hline & Welfare & -.129 & .090 & -.153 & -1.436 & .152 \\
\hline & Emergency & .103 & .065 & .148 & 1.576 & .017 \\
\hline & Workplace & .309 & .089 & .353 & 3.470 & .001 \\
\hline
\end{tabular}

a. Dependent Variable: Satisfaction

\subsubsection{Welfare Management Practices on Job Satisfaction}

The first hypothesis was; Hol: There is no significant effect of welfare management practices on job satisfaction. According to regression results in table 4, the values; $\mathrm{t}=-1.436$ and $p=0.152(<0.01)$ implies that there is no significant effect 
of welfare management practices on job satisfaction. The first hypothesis was accepted and made that welfare management has insignificant effect on job satisfaction. This implies that welfare management is a predictor of job satisfaction.

\subsubsection{Emergency Management Practices on Job Satisfaction}

The second hypothesis was; Ho2: There is no significant effect of emergency management practices on job satisfaction. The findings in table $4 ; \mathrm{t}=1.576$ and $\mathrm{p}=0.017(<0.01)$ implies statistically significant effect of emergency management practices on job satisfaction. The second hypothesis was therefore rejected and conclusion made that emergency management practices is a significant determinant of job satisfaction.

\subsubsection{Workplace Environment on Job Satisfaction}

The third hypothesis was; Ho3: There is no significant effect of workplace environment on job satisfaction. The values; $\mathrm{t}=3.470$ and $\mathrm{p}=0.001 \quad(<0.01)$ implies statistically significant effect of workplace environment on job satisfaction. The third hypothesis was therefore rejected and conclusion made that workplace environment is a significant determinant of job satisfaction.

\subsubsection{Occupational Safety and Health Management Practices and Job Satisfaction}

The last hypothesis was; Ho4: There is no significant effect between combined effect of occupational safety and health management practices and job satisfaction. R-square of 0.126 implies that welfare management practices, emergency management practices and work place environment management practices collectively predict/explain $12.6 \%$ of changes in job satisfaction. The ANOVA test gave $p$ value of $0.000(<0.01)$ implies that the effect is statistically significant. The last hypothesis is therefore rejected and conclusion made that occupational safety and health management practices are significant determinants of job satisfaction.

From table 2, the following multiple regression equation was developed for the study;

$$
\mathrm{Y}=3.193-0.153 \mathrm{X}_{1}+0.148 \mathrm{X}_{2}-0.353 \mathrm{X}_{3}
$$

Where; $\mathrm{Y}=$ Job Satisfaction

$\beta_{0}=$ Constant

$\beta_{1}-\beta_{3}=$ Regression coefficients

$\mathrm{X}_{1}=$ Welfare Management Practices

$\mathrm{X}_{2}=$ Emergency Management Practices

$\mathrm{X}_{3}=$ Work Place Environment Management Practices

\subsection{Conclusions}

Research on motivation or human factors has continued and on the basis of its findings, several improvements have been made with respect to the conditions of work. According to [14] the satisfaction of employees has not generally increased, perhaps for the reason that expectations of employees have simultaneously increased. The aim of the study was to determine the effect of selected Occupational Health and
Safety Management practices on employee job satisfaction in University Campuses in Nakuru Town. The study was guided by four objectives. Based on results from data analysis and findings in relation to the study objectives, the following conclusions were made;

First, the study concluded that that welfare practices had statistically significant positive effect on job satisfaction. The sensitization and provision of welfare services such as drinking water facilities, toilet facilities, canteen services and parking spaces in the work environment are likely to improve on the job satisfaction levels on the employees.

Secondly it was concluded that emergency management practices have statistically insignificant positive effect on job satisfaction. Therefore the provision of written emergency plan, first aid facilities, testing of emergency procedures, and presence of officers trained on disaster management, evacuation procedures, display of emergency contacts and display of evacuation procedures, employees training on the use of emergency will positively influence job satisfaction levels.

Thirdly, the study concluded that work place environment had statistically significant positive effect on job satisfaction. Provision of spacious enough, maintenance of furniture and equipment, prompt repairs on the broken infrastructure and putting in place measures to control and minimize risks in their work environment, regular cleaning and sufficient lighting will improve on the job satisfaction levels.

Lastly, the study concluded that the combined effect of occupational, health and safety management practices significantly influence employee job satisfaction levels. This means that an organization that strategically employees occupational, health and safety management practices is mostly to improve its employee job satisfaction levels.

\section{Recommendations}

The findings of this study revealed that the practice of occupational health safety and management practices leads to improved job satisfaction levels among employees in an organization. The study therefore recommends the following:

The creation and implementation of a policy that sensitizes and allows for provision of sufficient welfare services such as drinking water facilities, toilet facilities, canteen services and parking spaces in the work environment so as to improve job satisfaction levels of the employees in their work places.

The study further recommends to organizations to emphasize and to invest on the implementation of elaborate emergency management practices and plans. The provision of written emergency plan, first aid facilities in their work places, testing of emergency procedures, and presence of officers trained on disaster management, evacuation procedures, display of emergency contacts and display of evacuation procedures, employees training on the use of emergency equipment in their work places will positively influence job satisfaction levels and will in turn improve institution's image.

Thirdly, the management and organizations leadership are 
advised to take a proactive approach insofar as management of work environment practices and management are concerned. The adoption of such a recommendation would imply a concerted effort in preventive measures such as provision of spacious enough, maintenance of furniture and equipment, prompt repairs on the broken infrastructure and putting in place measures to control and minimize risks in their work environment, regular cleaning and sufficient lighting will improve on the job satisfaction levels.

\section{References}

[1] Alexander, P. \& Halpen, R. (2004). Introduction: comparing race and labour in South Africa and the United States. Rand Afrikaans University and University of Toronto: South Africa.

[2] Bamutire, B. M. (2007). Occupational health and safety management, teamwork and employee commitment: a case of Umeme Limited (Master's thesis) Makerere University, Kampala, Uganda. Retrieved from https://www.academia.edu/7268937/effects_of_occupational_ health_and_safety_on_job_performance_abstract.

[3] Burton, A., (2006): Human Experimentation: A rule Gone Awry Pub.

[4] Cascio, W. F. (1986). Managing human resources productivity, quality of life, and profit. New York: McGraw-Hill.

[5] Clements-Croome, D. \& Kaluarachchi, Y. (2000). Assessment and measurement of productivity. In: Clements-Croome, D. (ed.) (2000). Creating the productive workplace. London: E \& FN Spon.

[6] Cudjoe, S., F. (2011) "An assessment of occupational health and safety practices on job performance at the Tetteh Quarshie Memorial Hospital, Mampong-Akuapem” KNUST-Ghana.

[7] De Cieri, H. \& Kramar, R. (2003). Human Resource Management in Australia: strategy, people, performance. Sydney: McGraw-Hill.

[8] Den, H. \& Verburg, R. M. (2004). High performance work systems, organizational culture and firm effectiveness. Human Resource Management Journal. 14(1).

[9] Fernandes, B. H., Mills, J. F., Fleury, M. T. L. (2005). Resources that drive performance: an empirical investigation. International Journal of Productivity and Performance Management. 54(5/6).

[10] Gavin, T. \& Vinten, G. (2005). Job satisfaction in the workplace and its financial implications. Credit control, 26 (7).

[11] Henshaw, J. Gaftney, S. Madl, A. \& Paustenback, D. (2007): The employer's responsibility to maintain a safe and healthful work environment: a historical review of societal expectations and industrial practices. Springer Science Employee Response Right Journal. 19: 173-192.

[12] Kumar M. S., Goud, B. R., \& Joseph, B. (2014). A study of occupational health and safety measures in the Laundry Department of a private tertiary care teaching hospital, Bengaluru. Indian Journal Occupational Environmental
Medicine vol. 18, Issue 1, 2014. Retrieved on June 10, 2015, from http://www.ijoem.com/text.asp?2014/18/1/13/134951.

[13] Landy, F. J. \& Farr, J. L. (1983). The measurement of work performance: methods, theory and applications. Sydney: Academic Press.

[14] Locke, E. A. (1976). The nature and causes of job satisfaction. In M. D. Dunnette (Ed.). Handbook of industrial and organizational psychology (pp. 1297-1343). Chicago: Rand McNally Martin. K. W. \& Walters, B. J. (2001). Safety and health essentials for small business. Oxford: Butterworth-Heinemann.

[15] Nankervis, A. R., Compton, R. L., Baird, M. (2005). Human resource management: strategies and processes. Melbourne: Thomson.

[16] Nyakang'o, J. (2005). Status of occupational health and safety in Kenya: workshop on the safety training program, part of the Congress in Beijing.

[17] Ram, P. (2013). Relationship between Job Satisfaction and Job Performance in the Public Sector-A Case Study from India. International Journal of Academic Research in Economics and Management Sciences March 2013, Vol. 2, No. 2. Retrieved June 9, 2015 from www.hrmars.com/admin/pics/1676.pdf.

[18] Sanchez, J. I., Korbin, W. P., \& Viscarra, D. M. (1995). Corporate support in the aftermath of a natural disaster: E. Academy of Management Journal, 38(2), 504.

[19] Schabracq, M. J., Cooper, C. L., Winnubst, J. A. M. (2003). Introduction. In: Schabracq, M. J., Winnubst, J. A. M., Cooper, C. L. (2003). The Handbook of Work \& Health Psychology. England: John Wiley \& Sons.

[20] Spee, T. (2006). Occupational hygiene in Africa, annals of occupational hygiene. Oxford University. Journal of Occupational Hygiene.

[21] Taylor, G., Easter, K. \& Hegney, R. (2003). Advancing safety: a workplace guide 2. Perth: Work Safety and Health Associates.

[22] Veltri, A., Pagell, M., Behm M. and Das A. (2007). A data-based evaluation of the relationship between occupational safety and operating performance. Journal of SH\&E Research, Vol. 4, Num. 1 (2007).

[23] WHO. (1994). Global strategy on occupational health for all: the way to health at work; recommendation of the second meeting of the WHO collaborating centers in occupational health, 11-14 October 1994, Beijing, China.

[24] World Health Organisation. (2002). Good practice in occupational health services. A contribution to workplace health. WHO Regional office for Europe.

[25] WHO, (2008): Reducing workplace exposure to chemicals through risk management toolkit. Geneva: WHO.

[26] Wokutch, R. E. \& Van Sandt, C. V. (2000). OHS Management in the United States and Japan: The DuPont and the Toyota Models. In: Frick, K., Jensen, P. L., Quinlan, M., Wilthagen, T. (eds.) (2000). Systematic Occupational Health and Safety Management: Perspectives on an international development. Elsevier: Amsterdam. 